\title{
MARRIAGE WITHOUT WALI'S CONSENT: A PARADIGM SHIFT IN THE FAMILY STRUCTURE OF PAKISTAN
}

\author{
Muhammad Ifzal Mehmood* \\ Noraini Binti Md Hashim**
}

\begin{abstract}
In Islamic law, nikah is referred to as a civil contract. Thus, to fulfil a valid contract all the requisites of a valid marriage (arkan an-nikah) must be fulfilled. The majority of Muslim jurists opined that the consent of the guardian (wali) is one of the pillars determining the validity of marriage. Nevertheless, the Hanafi sect views that it as a mere condition for a marriage. In Pakistan, a precedent has been set in the Supreme Court's case of Saima Waheed, where it was decided that an adult Muslim woman can marry without the consent of her guardian. The decision ignited a debate on whether the consent of a guardian is a requisite pillar of a marriage contract or merely a condition to it. In order to comprehend the issue of wali's consent, it is essential to discuss the purpose of a marriage itself. This article discusses the importance of the wali's consent under Islamic law, followed by an elaboration on the legal status of a marriage without consent of the guardian under the Pakistani law. Besides arm-chair research, interviews were conducted with female respondents who had conducted their marriage without their wali's consent. The findings from these interviews indicate that marriage without wali's consent is shattering the family structure and causing isolation of the partners both from the family and the society. Irrefutably, approval of the guardians in marriage is essential in sustaining the family system.
\end{abstract}

Keywords: consent of guardian, wali in Islamic law, Pakistani marriage law.

* Ph.D candidate at Ahmad Ibrahim Kulliyyah of Law, International Islamic University Malaysia. Email: ifzaalmehmood@gmail.com

** Associate Professor at Ahmad Ibrahim Kulliyyah of Laws, International Islamic University Malaysia. Email: norainim@iium.edu.my. 


\title{
PERKAHWINAN TANPA PERSETUJUAN WALI: SATU PERUBAHAN PARADIGMA DALAM STRUKTUR KELUARGA DI PAKISTAN
}

\begin{abstract}
ABSTRAK
Di bawah undang-undang Islam, nikah merujuk kepada pembentukan sebuah kontrak antara seorang lelaki dan seorang perempuan. Oleh yang demikian, bagi menentukan kesahan perkahwinan, semua rukun nikah mestilah dipenuhi. Jumhur ulama' bersepakat bahawa keizinan wali adalah salah satu dari rukun nikah yang menentukan kesahan perkahwinan. Walau bagaimanapun, pandangan dari Mazhab Hanafi pula, ia bukanlah syarat penentuan sahnya perkahwinan. Di Pakistan, duluan kehakiman telah ditetapkan oleh Mahkamah Agung dalam kes Saima Waheed, di mana telah diputuskan seorang wanita Islam dewasa boleh berkahwin tanpa keizinan dari walinya. Keputusan ini telah memulakan perdebatan sama ada keperluan kepada izin wali adalah merupakan rukun nikah atau hanya syarat biasa. Untuk memahami isu keizinan wali, adalah amat penting untuk mengetahui tujuan perkahwinan itu sendiri. Makalah ini membincangkan kepentingan keizinan wali di bawah undang-undang Islam, diikuti dengan penerangan tentang kesahan status perkahwinan tanpa keizinan wali di Pakistan. Di samping penyelidikan di perpustakaan, temubual dengan responden wanita yang berkahwin tanpa keizinan wali juga telah dijalankan. Dapatan kajian dari temubual menunjukkan bahawa perkahwinan tanpa keizinan wali telah membawa kepada perpecahan kepada struktur keluarga dan masyarakat. Tidak dapat dipertikaikan bahawa keizinan wali dalam perkahwinan adalah amat penting demi mengekalkan sebuah sistem kekeluargaan yang mantap.
\end{abstract}

Kata kunci: persetujuan penjaga, wali dalam undang-undang perkahwinan Islam, undnag-undang perkahwinan di Pakistan

\section{INTRODUCTION}

Traditionally, the word guardian (wali) means a person who extends help. According to Islamic law, a wali is a person who has the authority to enter into a contract on behalf of a minor or insane person and gives 
consent and solemnises a woman's marriage for her during the nikah. ${ }^{1}$ Islam emphasizes on protecting the interests of women in all situations. In a Muslim family structure, there is a close bond of love and affection between the bride and her wali, to the extent that the marriage is to be solemnized by the wali on behalf of the bride. Not only that, the wali is also the advisor in all her life affairs, and the same manner applies when it comes to choosing her life partner. This is considered pertinent because as a protected woman, the bride remains inexperienced and less exposed to the social system and to men and the public in general. This restricts her ability to evaluate and judge men. On the other hand, the male guardian has more experience to choose a better partner for his ward. This was the belief among many Muslim societies that guard the bride from all aspects, be it safety, well-being to monitoring with whom a young lady befriends.

It is stated in the Qur'an and Sunnah of the Prophet (s.a.w) that consent of wali for the women is obligatory. However, there are occurrences of numerous marriages which are without a wali's consent during Prophet's (s.a.w) time, which is the main discussion of this article. The same situation took place in Pakistan, by virtue of Saima Waheed's case ${ }^{2}$, where the court has come to a decision that a woman may solemnize her own marriage. This article is divided into three parts; the first part will discuss on the importance of wali in marriage for women. In the second part, the writer will highlight authorities from the primary and secondary sources on the validity of consent of wali for a woman in her marriage. The last part will elaborate on the law regarding to consent of wali in other Muslim's countries in comparison with Pakistan

\section{CONSENT OF WALI}

Under Islamic law, guardianship implies a position of a person who bears certain authority on her/ his ward. A person who fulfils the

Abdurrahman al Baranji, Fiqh al Usrah al-Muslimah wa Nawazijoha fil Maghrib, (Cairo: Darul kutub al-Misriya, 2007), p.100.

$2 \quad$ PLD 1997 Lahore 301. 1997. 
criteria to have control over other's right is known as his/her wali, while in marriage, this person is also known as her wali. ${ }^{3}$

\section{Importance of Wali}

From the perspectives of classical and modern scholars, the consent of the wali is vital in order to protect the women's interest for numerous reasons, ${ }^{4}$ i.e., firstly, the wali plays the role of a advisor by recommending feasible advice on all aspects of the young woman's life. This view is endorsed from Prophet Shuaib's (a.s) practice where he advised his daughter to marry Prophet Musa (a.s). ${ }^{5}$ It is stated in the Qur'an:

Said one of the (damsels): O my (dear) father! Engage Him on wages: truly the best of men for Thee to employ is the (man) who is strong and trusty. ${ }^{6}$

He said: I intend to wed one of these My daughters to thee, on condition that Thou serve me for eight years; but if Thou complete ten years, it will be (grace) from thee. But I intend not to place Thee under a difficulty: Thou wilt find me, if Allah wills, one of the righteous. ${ }^{7}$

He said: Be that (agreement) between me and thee: whichever of the two terms I fulfil let there be no ill-will to me. Be Allah a witness to what we say. ${ }^{8}$

3 Noraini Binti Md Hashim, "Registration of Marriage in Malaysia: A Socio-legal study of Runaway Marriages Among Muslims, " (Ph.D Thesis, IIUM, 2009), p.166.

4 Aziz Mohd, Badruddin Ibrahim \& Shafi'iqah Abul Razak, Protecting Women's Interest (Maslahah) in Marriage Through Appointment of a Guardian (Wali) Under Islamic Law, Social Sciences \& Humanities, Vol.23 (2015), p.80.

5 Ibid.

6 Surah al-Qasas (28), verse 26. Abdullah Yusuf 'Ali. The Holy Qur'an. Arabic Text with English Translation of the Meaning \& Selected Commentaries. Saba Islamic Media: Kuala Lumpur.

7 Ibid verse 27.

8 Ibid verse 28. 
Sayyid Qutub interprets that Prophet Shuaib (a.s), found a healthy and pious person and her daughter was also inclined towards him. So, he offered him his daughter in marriage..$^{9}$ It is clear from the verse that the wali chooses a person who bears good character and his advice of marriage for his daughter was proved to be right. There was also evidence that his daughter also approved of the choice as she was inclined to him.

Secondly, the dependence on a wali is necessary because the cautious nature of a woman makes it difficult for her to ascertain the amount of dower. In the given social conditions, the bride feels shy to negotiate on her own dower, so, the male guardian can determine the amount for her. ${ }^{10}$ This may be due to the emotions of a woman which may make her hesitant in putting forward a definitive amount for her mahr. ${ }^{11}$

Thirdly, the wali plays a role as a protector for the woman, safeguarding his ward from any intentional deceiver because he is supposed to be much wiser in making decisions. ${ }^{12}$ Hammudah 'Abd Al-'Ati writes that it is a responsibility assigned to the wali to safeguard the ward's welfare. He further states that the guardian usually looks at his experience as a male and with that regard, decide his best opinion for his ward's marriage. The father has love and affection for his children and thus, is expected to be more careful in choosing their children's partner by meeting certain moral and personal qualities. $^{13}$

Lastly, the approval of a wali has another social significance in strengthening the family ties. Hence, the consent of a wali is supposed to ensure mutual understanding and happiness of all parties, where should any case of misconception or argument arise between the

9 Sayyid Qutb, In the Shade of the Qur'an, (UK: The Islamic Foundation, 2003) vol. XIII, p.221.

10 Azizah Mohd, p.81.

11 Syed Sabiq, Fiqh al-Sunnah, (Egypt: Dar ul-Kutub al-Islami, n.d) vol.2, p.113.

12 Azizah Mohd, p.80.

13 Mammudah 'Abd Al - 'Ati, The Family Structure of Islam, (Selangor Malaysia: The Other Press, 2008), p.84. 
husband and wife, their families will take responsibility in helping them to sort it out. ${ }^{14}$

\section{Authorities in Qur'an and Sunnah}

The requirement of for a wali's consent in a marriage have been stated in the Qur'an and Sunnah. A verse from Qur'an on the issue of wali states that, "... therefore you may marry them with the permission of their guardians and give them their dower so that they may live a decent life in wedlock" ${ }^{15}$ In another verse it is stated, "... and Allah is most knowing about your faith. You [believers] are of one another. So, marry them with the permission of their people and give them their due compensation according to what is acceptable. [They should be] chaste, neither [of] those who commit unlawful intercourse randomly nor those who take [secret] lovers...". ${ }^{16}$ In both verses, it is clearly mentioned that permission of a wali is obligatory.

The principle of wali was also stated in the hadith, as an obligatory element for the solemnisation of marriage. It is narrated from Aisha (r.a) that the Prophet (s.a.w) said:

The marriage of a woman who marries without the consent of her guardians is void. (He (s.a.w.) said these words) three times. If there is cohabitation, she gets her dower for the intercourse with her husband. If there is a dispute, the Sultan (man in authority) is the guardian of one who has none. ${ }^{17}$

Abu Musa (r.a) narrates a hadith that says, "There is no marriage without the permission of a guardian". ${ }^{18}$ In another hadith Aisha (r.a)

14 Azizah Mohd, p.81.

15 Surah an-Nisa'(4), verse 25. Abdullah Yusuf 'Ali. The Holy Qur'an. Arabic Text with English Translation of the Meaning \& Selected Commentaries. Saba Islamic Media: Kuala Lumpur.

16 Surah an-Nisa'(4), verse 25. Abdullah Yusuf 'Ali. The Holy Qur'an.

17 Al-Tirmidhi, Sunan al-Tirmidhi, Kitab al-Nikah, (Beirut: Dar al-Gharab al-Islami, 1981), Vol.2, p.398. see also Narrated by Sunan Abu Dawud, Kitab al Nikah, Book 5, Number 2078, also stated in Ahmad 24417.

18 Ibn Majah, Abu Abdullah Muhammad Ibn Yazid al-Qazwini, Sunan Ibn Majah, Kitab al-Nikah, (Hadith No.1880) (Dar Ihya' al-Kitab al'Arabiyyah), Vol.2, p.605. 
states that, "Her father gave her in marriage with Prophet (s.a.w) when she was six years old and $\mathrm{He}$ (s.a.w) established matrimonial relationship with her when she was nine years old' ${ }^{19}$ It could be argued from the verses of Qur'an and the sayings of the Prophet (s.a.w) that a virgin girl must obtain the consent of her wali before solemnisation of the marriage.

\section{Juristic Views}

Muslim jurists from different schools of thought bear varying opinion on the consent of the wali in marriage. The Shafi' $i$, Maliki and Hanbali jurists opines that the consent of wali is compulsory for the solemnisation of marriage. While the Hanafi jurists consider the consent of the wali merely as a condition for a valid marriage. Imam Shafi'i writes, "if a woman married without the consent of her guardian, her marriage is void" ${ }^{20}$ He legalised his stance from the verse 25 of Surah an-Nisa'. In the famous book on fiqh of Shafi'i's school, Al-Fiqh Al-Manhaji, it is stated that consent of the wali is considered as pillar of a marriage. It is indicated in his book that a female adult, a widow or a virgin should be given in a hand of marriage by her guardian. ${ }^{21}$ They took above interpretation from the hadith narrated by Abu Hurairah in which the Prophet (s.a.w) said:

No woman should arrange marriage of another woman, and no woman should arrange her own marriage. The adulteress is the one who arrange her own marriage. ${ }^{22}$

The principle that a father has the authority of marrying his virgin daughter without her consent has thus been formulated based on these authorities. However, the Islamic law advocates a father to first consult his daughter before arranging her marriage. The necessity of the

19 Sahih Muslim, Kitab al-Nikah, Bab Tazwij al-Ab al-Bikar al-Saghirah.

20 Muhammad bin Idrees Al-Shafi'i, Kitab Al-Umm, (Beirut: Dar-ul-Kutub Al Gilmiya, 1993), p.12.

21 Mustafa Al-Khin, Mustafa Al-Bugha \& Ali Al-Sharji, Al Fiqh Al-Manhaji ala Mazhab Al-Imam Al Shafi, (Beirut: Al Dar Al-Shamiya, 2008), Vol.2, p. 57.

22 Ibn Majah, Sunan Ibn Majah, Vol.3, Book 9: 1882. 
consent of a female is also clearly mentioned in another hadith which mentions:

A widow or divorced woman has more right to her person than her guardian, and a virgin's consent must be asked from her, and her silence implies her consent. ${ }^{23}$

Although this authority specifically mentions a "widow or divorcee" the fact that the hadith mentions the need for her consent to be obtained shows that the holy Prophet s.a.w did consider the pertinence of obtaining the consent of a woman for a marriage. Nevertheless, many Muslim jurists are inclined to the view that this applies only in cases where the daughter is a widower or divorcee but not a virgin. ${ }^{24}$

The Maliki jurists emphasises on the importance of the consent of wali for a woman in her first marriage and later is allowed to freely enter into her second marriage. ${ }^{25}$ Hanbali jurists are also of the same opinion that a marriage could not be conducted without the consent of a wali. ${ }^{26}$ However, Imam Ahmad bin Hanbal does not consider it as a pillar (rukun) but rather a compulsory condition (shart li sihat al-nikah) for the completion of her marriage. ${ }^{27}$ While the Hanafi jurists hold the stance that a virgin woman can enter into a marriage without the consent of her wali. Their argument is that after puberty a lady can make decisions for herself. It would not be allowed for the wali to arrange the marriage of his virgin daughter against her will. ${ }^{28}$ They refer this opinion from the authority of Qur'anic verse:

And when you divorce women and they end their term of probation('iddah), do not prevent them from marrying her husband when they agree among themselves in lawful manner. ${ }^{29}$

23 Sahih Muslim, Book 8,: 3306.

24 Abu Zakaria Yahya Ibn Sharif En Nawawi, p.284.

25 Ibid.

26 Ibn Qudamah, Al Mughni, (Beirut: Dar ul Aalam Al-Kutab, 2005), vol.9, p. 345 .

27 Mustafa Abdul Qadir Ata, Ahkam Al-Ziwaj 'Ala Al-Mazahib Al-Arbe, (Beirut: Dar-Ul Kutub Al-Gilmiya, 1986), p.118.

28 Burhanuddin Abi Al-Hasan Ali Marghinani, The Hidaya, trans Charles Hamilton, Vol.1, Part.1 (Karachi, Darul Ishat, 2005), p.65.

29 Surah al-Baqarah (2): verse 230. Abdullah Yusuf Ali, The Holy Qur'an. 
From this verse, the Hanafi jurists contended that a woman is free to marry without the consent of a wali. They argued from the precedent of Saidatina Aishah when she arranged the marriage ceremony of her brother's daughter while her father was not present. ${ }^{30}$ Moreover, in $a l$ Bahr al-Ra'iq it is argued that, "Everyone whom the law permits to dispose of their property acting as their own guardian, it also permits them to marry and act as their own guardian". ${ }^{31}$ They also relied on another Hadith, "A virgin came to the Prophet (s.a.w) and mentioned that her father had married her against her will, so the Prophet (s.a.w) allowed her to exercise her choice". ${ }^{32}$ The Hanafi jurists interprets this hadith as meaning a father does not have any right to force his virgin daughter into a marriage.

From the above discussion, it could be argued that the majority of the Muslim jurists prefers the consent of the wali as a pillar of marriage, while the Hanafi view remains the minority opinion. After analysing the earlier referred hadith when Saidatina Aishah (r.a.) married her niece without her brother's consent, some of the Muslim jurists commented that in that case, Saidatina Aishah (r.a.) had exercised the rights of her guardianship because she did not want to lose a better proposal. In the Hadith where the Prophet (s.a.w) declared the marriage as void to the bride's choice, Imam Shafi'i says that this hadith regards the authority of wali in the marriage of a widow and a virgin, where the virgin must seek permission from her wali, while the widow is authorised to solemnize her own marriage. On the basis of this hadith, a widow's opinion is privileged over their wali's desire. It can be argued from the above discussion that according to the majority opinion, the wali has more rights over the virgin girl and her marriage will be organized upon the approval of guardian. ${ }^{33}$ Even Imam Abu Yousuf, the disciple of Imam Abu Hanifah states that a marriage could not be solemnized except through her guardian. ${ }^{34}$ While the student of Imam Abu Hanifah, Imam Muhammad states that if a marriage is not

30 Muhammad Simarah, Ahkam wa asar al-Zawjiya Sharah Maqarin li Qanoon al Ahwal al-Shakhsiyah, (Oman: Darul- Al Saqafah, 2008), p.85.

31 Ibn Nujaym, al-Bahr al-Ra'iq, (Cairo: Maktabat al-Majidiyah, 1968), vol.3, p.117.

32 Sunan Ibn Majah, Vol.3, Book 9, Hadith No.1875.

33 Muhammad Shamsul Al Haq Azim Abadi, An'nul Ma'bud, (Darul Fikar, 1995), p.96.

34 Marghinani, The Hidaya, p. 65. 
conducted in the presence of a wali, the marriage can only be solemnized after attaining the consent of wali. ${ }^{35}$ This means that the marriage cannot be solemnized without the consent of a wali.

\section{Marriage Legislation in Other Muslim Countries}

Family laws vary in Muslim countries due to different school of thoughts. On the matter of the consent of the wali, some Muslim countries recognised it as compulsory requisite in marriage. While in other countries, such a consent is only required if the female is a minor and/or an insane person. ${ }^{36}$ In Malaysia, the Islamic Family Law (Federal Territories) Act 1984 states that,

A marriage shall not be recognised and shall not be registered unless both parties to the marriage have consented, and either the wali of the woman has consented or the Shari'ah judge has granted his consent as wali Raja whenever there is no wali nasab available to act or if the wali cannot be found or where the wali refuses his consent without sufficient reason. ${ }^{37}$

This law is adequate although it is not clear that whether the law mentions about the consent of a al-thayyibah (a widow) or a al-bikr (a virgin). Another confusion relates to the wali is whether the act mentioned wali as the bride's father or her grandfather or any other wali nasab. ${ }^{38}$ The law in the state of Kelantan (Malaysia) adopts the Shafi'i school of thought, which states that,

A woman who is to be married should first give permission to her wali, her consent being wajib if she is not a virgin or if she is virgin whose wali is not mujbir, but her consent being only sunat if she is a virgin whose wali is mujbir i.e her father or paternal grandfather. ${ }^{39}$

35 Ibid.

36 Muhammad Tahir Mansoori, Family Law in Islam, (Islamabad: Islamic Research Institute Press, 2009), p.66.

37 Islamic Family Law (Federal Territories) 1984, Section 13.

38 Nik Noriani Nik Badli Shah, Marriage and Divorce under Islamic Law, (Selangor: International Law Book Service, 1998), p.15.

39 Kelantan Islamic Family Law Enactment 1983, section 2(e). see also Nik Noraini Nik Badli Shah, p.15. 
This provision and similar relevant provisions in the Islamic Family Law Act and Enactments of each State in Malaysia, clearly shows that in order for a bride to marry, she must get the consent of the wali.

If examination is made to the Family Code of Algeria, a similar trend exists, whereby it states that, "marriage of a woman shall be contracted by her marriage guardian, who may be her father or one of her near relatives. The Qadi is the marriage guardian of a person who has no father or near relative." ${ }^{40}$ Meanwhile, the Libyan Law has a unique stand where it states that,

It is not be lawful for the guardian to compel the ward in respect of marriage. So, where a marriage has been contracted with the consent of the guardian it shall be valid, but where either the guardian or the ward contracts without the consent of the other, its validity will depend on the consent of the other. ${ }^{41}$

Hence, The Libyan Law recognises that both the consent of the bride and the guardian as essential. This position has also been adopted by the family law of Sudan, which endorses the consent of the woman and her guardian as essential for the validity of the marriage. The law provides that, "the marriage of a girl which is not contracted by the legal guardian either personally or through delegated authority shall be ineffective." 42

Similarly, the personal law of Somalia also gives importance to the consent of wali which is quite similar to the Malaysian position. The Somalian Family code mentions that, "a girl of sixteen but below eighteen years of age can marry, with her guardian's consent". ${ }^{43}$

\section{ISSUES RELATING TO SAIMA WAHEED'S CASE}

\section{Love marriage}

Love marriage is a term used in Pakistan (including India, Bangladesh and Sri Lanka) to describe a marriage where individuals decide to marry without the consent of their parents, or by an arrangement

\footnotetext{
40 The Family Code 1984, Art. 11.

41 Law on Women's Rights in Marriage and Divorce 1972, Art.2.

42 Law on Marriage-Guardianship 1960, [Manshur 54 of 1960], art.1.

43 The Family Code 1975, art.16.
} 
between themselves. ${ }^{44}$ In a few cases, this happens when the daughter's intention to marry a man of her choice is rejected by her guardian, she will elope. Elopement that takes place, which is without the approval of their guardian is regarded as an irregular marriage. ${ }^{45}$

\section{Dowery (Mahr)}

The dowery is the compulsory payment made by the husband to the wife prior to the marriage. It is a gift from the husband which may be in the form of money or property for the wife in consideration of a marriage. ${ }^{46}$ All Sunni schools of thought agree that the mahr is the basic condition for the marriage and marriages will not be valid without it. ${ }^{47}$ They concluded their opinion from the following verses of Holy Qur'an:

And give woman their dowers as a free gift. ${ }^{48}$

And lawful for you are all women besides these, provided that you take them in marriage not committing fornication. Then as to those whom you profit by (through marriage), give them their dowers as appointed. ${ }^{49}$

And the chaste from among the believing women and the chaste from those who have been given the Book before you, when you have given them their dowers, taking them in marriage..$^{50}$

44 Love marriage, available on https://en.wikipedia.org/wiki/Love_marriage [Accessed at 23th January 2018].

45 Mohammad Samara, AÍkam wa Asar Al-Zawjiyah sharí maqarin lil qanon al-Ahwal Al-Shakhsiyyah, (Oman: Darul Saqafah lil nashr wa al-tawzeh, 2002), p.150.

46 'Abdur Rahman I. Doi, Woman in Shari'ah, (Kuala Lumpur: A.S Noordeen, 1992), p.155.

47 Muhammad Tahir Mansoori, p.71.

48 Surah al-Nisa'(4):4. Abdullah Yusuf 'Ali. The Holy Qur'an.

49 Ibid, Surah al-Nisa' (4):24.

50 Surah al-Maidah (5):6. Abdullah Yusuf 'Ali. The Holy Qur'an. 
It is obvious from these verses of the Holy Qur'an that the mahr is compulsory payment by the groom in fulfilment of a valid marriage. The same conclusion is also interpreted from a few ahadith of the Prophet (s.a.w). The bride should specify the amount of dowery in their marriage ${ }^{51}$ and the dowery could be paid at the time of or after the marriage had been solemnised, and the amount of the mahr will be specified according to the social status of the wife or as mutually agreed upon between the parties and their families. ${ }^{52}$ The wife has the right to remit the whole or partial mahr but Saidina Umar (r.a.) decided that after remission if the wife demands later, the husband would still be bound to pay. ${ }^{53}$ The mahr is the property of the wife which she can use at any time and it serves as a safeguard for the wife if her husband later divorces her. To favour the bride and groom, Islam also permits to pay mahr in one's marriage with anything according to his financial situation and even the Prophet once organised a marriage ceremony of a couple with the memorisation of Qur'an as her mahr. ${ }^{54}$

In Pakistan, the mahr is specified in the marriage but with the situations of love marriage or elopement and court marriage; the amount of mahr is less or has been remitted by the wife. This is because the fixation of the mahr is not initiated by the wali but between the parties themself. Consequently, the partners are not aware of the importance, but particularly to a woman/wife, she will realize its significance when she is being left by her partner without any support..$^{55}$

\section{Legislation in Pakistan}

In Pakistan, the solemnisation of a marriage is regulated by the Muslim Family Law Ordinance 1961(MFLO), however, it is mainly concerned with the procedural part of the marriage. So, the authority of the

51 Sadiya Quraishi, Interviewed by researcher, Sindh Pakistan, 28 December 2017.

52 Abul A'la Mawdudi, The Law of Marriage and Divorce in Islam, (Kuwait: Islamic Books Publishers, 1983), p.51.

53 'Abdur Rahman Doi, p.56.

54 Sunan Abi Dawud, Kitab Al-Nikah, Bab al-Tazweej 'ala al-mal, Hadith No. 20111.

55 Shamim Akhtar, Interviewed by researcher, Sindh Pakistan, 28 December 2017. 
substantive aspects is vested in courts. ${ }^{56}$ It is found that Pakistani law is silent on the matter of the guardian's consent in the marriage. Moreover, the legislation regarding forced marriage is also not determined in Pakistan. In Pakistan, even in a case of a new born daughter or even the child still conceived by the mother, she is sometimes be given in hand of marriage by her parents to a person of their choice. ${ }^{57}$ So, even if an infant, parents may arrange their daughter's marriage and the solemnisation of the nikah is conducted by the wali, regardless of whether she is a minor or a major.

However, the injustice in society could not be hidden from the Pakistani courts. Pakistan is a common law country and the precedent of the court is also considered as a source of law. It was discovered in the case of Humaira Mehmood vs. The State ${ }^{58}$ that the appellant came to the court to appeal to drop the criminal charges against her. She stated to the court that she has entered into a marriage against the consent of her parents. It was said that her parents already arranged her marriage when she was still a child. When her parents came to know about her marriage, they lodged a police report and the parties were wrongly jailed for adultery charges. She was forced to marry her cousin while her marriage was still subsisting. Humaira filed a petition in Lahore High Court stating that her second marriage was under duress and should be pronounced void. ${ }^{59}$ The court decided in her favour and held that according to Islamic Law, the Constitution of Pakistan and international human rights it is the right of a female to freely enter into a marriage without the consent of the wali. In another case of Muhammad Tariq Mahmood vs. SHO ${ }^{60}$ the court also made an observation on the issue of wali's consent. The Lahore High Court decided that a woman could conduct her marriage without the consent of her guardian.

56 Karin Carmit Yefet, What's the Constitution Got to Do with it? Regulating Marriages in Pakistan, Duke Journal of Gender Law \& Policy, vol.16 (2009), p.351.

57 Rashid Mohammad Husain Patel, Woman Verses Man: Socio-Legal Gender Inequality in Pakistan, (New York: Oxford University Press, 2003), p.55.

58 PLD 1999 Lahore 494, at p.514.

59 PLD 1999 Lahore 494, at p.514.

601997 PCrLJ 758 (Lahore). 
This position was however cemented in the landmark decision of Supreme Court of Pakistan was found in the case of "Saima Waheed's case." Saima Waheed was a twenty-two-year-old student when she married without the consent of her guardian. She moved to a female shelter after receiving threats from her own family. Her husband was tortured and imprisoned. In response, Saima appealed that she had married according to her own wishes and wished to freely live with her husband.$^{61}$ Questions were raised by the court and the opinion of the majority of the Islamic jurists was sanctioned as well. Justice Ihsan-ulHaq said:

Marriage in Islam is a sacrament and not a civil contract; that rights of parents in this regard were legally enforceable and that an adult Muslim woman could not enter into a valid contract of marriage without the intervention of her guardian. ${ }^{62}$

The court discussed the issue of wali in a marriage according to Islamic law and reviewed the opinions of the four Muslim jurists. ${ }^{63}$ The opinion of three jurists was accepted by the court, and the ruling validated the fundamental rights given by the constitution of Pakistan. The Lahore High Court handed down a conflicting decision and for which the case was brought to the Supreme Court of Pakistan. ${ }^{64}$ The Supreme Court decided the case on the same line of argument as was adopted by the Lower High Court in Muhammad Tariq Mahmood vs. SHO, Millat Park $^{65}$, Lahore, albeit in a more refined manner. The court issued a detailed judgement and endorsed the view of Saima Waheed. The precedent of Supreme Court is now followed in every court and this has opened the door for younger generation to go against the will of their guardians in marriage.

\footnotetext{
61 Abdul Waheed vs Asma Jahangir PLD 1997 Lahore 301.

62 Ibid.

63 Karin Carmit Yafet, What's the Constitution Got to Do with it? Regulating Marriages in Pakistan, p. 358.

64 Hafiz Abdul Waheed v Asma Jehanghir PLD 2004 SC 219.

651997 PCrLJ 758 (Lah).
} 


\section{Effects of Saima Waheed's Case}

The family is the first social structure for man, where he learns good manners, discipline, world view and religious belief. It is widely established that all religions have given significant importance to the family structure. ${ }^{66}$ For this reason, all religions recommend strengthening the family structure. The marriage bond is not only a combination of two individuals but it unites two families. ${ }^{67}$ Thus, if the marriage is conducted only between the parties, then the real purpose of marriage is not achieved.

In the aftermath of Saema Waheed's decision; the writer opines that the young generation is destroying the family bond by following their heart. It is noticed that the couples who have conducted love marriages or eloped marriages as well as court marriages are isolating themselves from their families. At the same time the bride's family usually lose their reputation and status in the society and is being treated as outcasts. During the interviews conducted by the writer, the respondents shared their opinion gained through their love marriage experience. Firstly, a female respondent said that the youth must be given religious education since young. The love marriages that they endured merely because of following their heart their and ignorance of religion and the consequences will only be faced later. This point of view is also observed by another female respondent who said that surely as parents, they, themselves would not want the same act to happen when their children grew up, and pursue their marriage on their own, similarly as their parents did. ${ }^{68}$ Secondly, these couples are isolated from their families and society and usually lives in seclusion. ${ }^{69}$ Thirdly, the brides face mental and emotional torture by the society for a long time and are ashamed.$^{70}$ Fourthly, the love marriage is risky for the woman as usually the male partner is accepted by his family and the bride remains in cul-de-sac. The woman feels kerbed to search for

66 John H. Chamberlayne, The Family in Islam, International Revive for the history of religions, vol.15 (1968), p. 119-141.

67 Saima Waheed case,p. 327.

68 Sadaf Naz, Islamabad, interviewed by researcher, Islamabad Pakistan, 31 December 2017.

69 Irum Shahzad, interviewed by the Researcher, Islamabad, 2 January 2018.

70 Sadiya Quraishi, Sindh. interviewed by the Researcher, Islamabad, 2 January 2018. 
jobs to survive and lives a troublesome life. ${ }^{71}$ And lastly, love marriage couples pass a disgraceful life and they are curbed by their families and society. ${ }^{72}$

\section{CONCLUSION}

The consent of the wali is a pre-requisite for a bride to marry. It is based on the verses of the holy Qur'an and the Sunnah of the Prophet (s.a.w). The majority of the Muslim jurists also declared the consent of wali as fundamental. Nevertheless, in Pakistan there is no procedural law where the consent of wali for bride is determined. In Saima Waheed's case the court set the precedent that consent of wali for a bride is not necessary. Although Justice Ihsan U1 Haq Chaudary commented that it is necessary for the woman to marry according to the wishes of her guardian but also condemned the act of guardian arranging the marriages of their children in early age. The decision of Supreme Court in Saima Waheed set a precedent for youths in Pakistan and thus adversely affecting the family structure. Moreover, it is found from the interviews with the respondents that they live in social isolation and lead a miserable life. It is recommended that the legislations of other Islamic countries (i.e., Malaysia, Algeria, Libya, Sudan, Somalia and Syria) be taken as guides to safeguard the interest of partners and social norms of society. Furthermore, the social structure of society is at risk due to love marriages.

71 Humaira Khalid, interviewed by the Researcher, Islamabad, 2 January 2018.

72 Shamim Akhtar, Sind, interviewed by the Researcher, Islamabad, 2 January 2018. 